\title{
1 New geochemical and geochronological data on the Cenozoic Veneto Volcanic
}

2 Province: geodynamic inferences

4 Brombin V. ${ }^{\mathrm{a}, \mathrm{b}}$, Pettitt E.A. ${ }^{\mathrm{c}}$, Fahnestock M.F. ${ }^{\mathrm{c}}$, Casalini M. ${ }^{\mathrm{d}}$, Webb L.E. ${ }^{\mathrm{e}}$, Bryce J.G. $^{\mathrm{c}}$, Bianchini

$5 \quad$ G. ${ }^{\mathrm{a}, \mathrm{b}, *}$

6

7 a Department of Physics and Earth Sciences, University of Ferrara, Via G. Saragat 1, 44122,

8 Ferrara, Italy

$9 \quad{ }^{\mathrm{b}}$ Institute of Environmental Geology and Geoengineering of the Italian National Research Council

10 (CNR-IGAG), Rome, Italy

$11{ }^{c}$ Department of Earth Science, University of New Hampshire, Durham, NH 03824, New

12 Hampshire, USA

13 d Department of Earth Sciences, University of Florence, Via G. La Pira 4, 50121, Florence, Italy

14 e Department of Geology, University of Vermont, Burlington, VT 05405, Vermont, USA

15

$16 *$ corresponding author: bncglc@unife.it

18 Keywords: Veneto Volcanic Province, intraplate magmatism, ${ }^{40} \mathrm{Ar} /{ }^{39} \mathrm{Ar}$ and $\mathrm{K} / \mathrm{Ar}$ geochronology,

19 Giudicarie Fault System, poloidal mantle flow.

20

21 Highlights:

22 - VVP intraplate magmatism occurred in the South Alpine foreland during Cenozoic.

23 - The mantle source is a garnet-peridotite metasomatized by carbonatitic fluids.

24 - The isotopic ratios of VVP conform to the European Asthenospheric Reservoir signature. 
- VVP magmatism climax was in the Eocene as the orogenic magmatism along the Periadriatic Line.

- VVP magmatism was induced by an asthenospheric poloidal mantle flow passing through a slab tear.

\section{Abstract}

The Veneto Volcanic Province (VVP; NE Italy) is an intraplate magmatic area whose activity occurred intermittently in the Cenozoic, generating five districts (Val d'Adige, Lessini Mts., Marostica Hills, Berici Hills, and Euganean Hills). This intraplate magmatism was concomitant to the collision of the European plate and Adria microplate and the orogenesis of the neighboring Alpine belt. Different geodynamic models suggested relationships between VVP and the coexisting subduction processes. To give new insights on this on-going debate, this work provides new petrographic and geochemical data, including $\mathrm{Sr}-\mathrm{Nd}-\mathrm{Pb}$ isotopic and ${ }^{40} \mathrm{Ar} /{ }^{39} \mathrm{Ar}$ and $\mathrm{K}-\mathrm{Ar}$ geochronological analyses for lavas sampled in the Lessini Mts. and Val d'Adige, which are the oldest VVP magmatic districts, as well as Marostica Hills and Berici Hills, which are the least investigated districts. The trace element distribution indicates that VVP melts were variously affected by metasomatic enrichments stabilized as phlogopite and/or amphibole. The $\mathrm{Sr}-\mathrm{Nd}-\mathrm{Pb}$ ratios conform to the dominant features of sub-lithospheric mantle components widespread at regional scale throughout the whole European and Mediterranean area. Within this framework, the geochronological data indicate that the oldest magmatic episodes occurred in the Eocene (45-42 Ma) in the Lessini Mts. and Val d'Adige, simultaneously with the orogenic magmatism of Adamello intrusive complex along the Giudicarie Fault, a portion of the Periadriatic lineament which is an important Alpine suture. In our geodynamic reconstruction we propose that the Giudicarie Fault is the superficial expression of a slab tear, responsible for the uprising of an asthenospheric poloidal mantle flow, which induced both the Adamello and VVP magmatism. Subsequently, VVP activity migrated toward eastwards following 
the general mantle flow as indicated by minor volcanic pulses in the Euganean and Marostica Hills during Oligocene and Miocene.

\section{Introduction}

The Paleogene convergence of the European plate with the Adria microplate led to the formation of the Alpine belt (Handy et al., 2010, 2015; Wiederkehr et al., 2009) and the occurrence of Cenozoic orogenic (subduction-related) and anorogenic (intraplate-like) magmatic activities along the Periadriatic line and in the Southeastern Alpine domain, respectively (Fig. 1a, b; Beccaluva et al., 2007; Bellieni et al., 2010; Bergomi et al., 2015; Brack, 1984; Brombin et al., 2019; Callegari and Brack, 2002; Conticelli et al., 2009; Ji et al., 2019; Kagami et al., 1991; Macera et al., 2003; 2008; Schaltegger et al., 2019). In the mid-Nineties, the occurrence of syn- and post-collisional magmatism along the Periadriatic line was investigated by Davies and von Blanckenburg (1995), which introduced for the first time the slab breakoff model. According to this theory, the Periadriatic magmatism near the subduction zone is the effect of mantle upwelling through a slab window, after the slab breakoff of the subducting European plate, which probably occurred $\sim 35 \mathrm{Ma}$ (Dézes et al., 2004; Rosenbaum and Lister, 2005; Stampfli et al., 1998, 2002). The same geodynamic interpretation was also applied to explain the occurrence of intraplate-like magmatism in the Southeastern Alpine domain, which generated the Veneto Volcanic Province (VVP; De Vecchi and Sedea, 1995; Fig. 1), i.e., one of the largest Cenozoic magmatic districts of the Adria Plate. Macera et al. (2003) proposed that the VVP was related to mantle diapirs, which were sucked into the European slab window and upwelled towards shallower levels heating the overriding Adria plate, triggering partial melting, and finally, inducing the VVP magmatism. However, recent high-resolution tomographic images displayed an unbroken subvertical European slab (Hua et al., 2017; Salimbeni et al., 2018; Zhao et al., 2016). In the absence of robust evidence for slab breakoff, several authors proposed alternative geodynamic interpretations for the occurrence of the Cenozoic magmatism in the Alpine domain. Such interpretations have been formulated mainly investigating new geochronological data in order 
to reconstruct the temporal evolution of the magmatic activities in the Alpine domain. Interestingly, the geochronological studies also indicated that the magmatic activities in the Alpine domain began before the supposed slab breakoff (i.e., $35 \mathrm{Ma}$ ). Using zircon $\mathrm{U}-\mathrm{Pb}$ ages from the main Periadriatic intrusives of the Western (Traversella and Biella) and Central (Bregaglia and Adamello) Alps, Ji et al. (2019) demonstrated that several magmatic events started synchronously along the Periadriatic line since the middle Eocene ( $45 \mathrm{Ma}$ ) and proposed that the Periadriatic magmatism was triggered by a mantle corner flow, induced by the progressive European slab steepening. Brombin et al. (2019) reconstructed the intraplate magmatic activity of the VVP from the Eocene to early Miocene, on the basis of new ${ }^{40} \mathrm{Ar} /{ }^{39} \mathrm{Ar}$ ages of VVP magmatic products. These authors invoked the upwelling of a poloidal mantle flow, overpassing the front edge of the steeping slab to explain the occurrence of VVP magmatic activities. However, considering that the beginning of the VVP magmatic activity is not well defined, new geochemical, isotopic, and geochronological analyses are necessary to understand the onset of the VVP volcanism within the Alpine tectono-magmatic framework. The main goal is to provide a new geodynamic explanation for the spatial-temporal contiguity of the intraplate basic magmatic products typical of the VVP and the orogenic magmas outcropping northward along the Periadriatic fault system that is one of the main tectonic discontinuities of the entire Alpine belt. In this light, this work contributes to recognize deep features of the Alpine geodynamic architecture.

\section{Geological overview}

During the Cenozoic, the southeastern Alpine domain was affected by effusive to subvolcanic magmatic activity, mainly basic-ultrabasic in composition, that took place intermittently from the late Paleocene to the early Miocene (Bassi et al., 2008; Beccaluva et al., 2007; Brombin et al., 2019; De Vecchi and Sedea, 1995; Macera et al., 2003). Most of the magmatic products crop out intermittently over a NNW-SSE elongated area of about $1500 \mathrm{~km}^{2}$ and formed five main VVP magmatic districts: Val d'Adige, Lessini Mts., Marostica Hills, Berici Hills, and Euganean Hills (Beccaluva et al., 2007) 
102 (Fig. 1). According to the temporal reconstruction of VVP magmatic activities reported in the 103 literature (Brombin et al., 2019, and reference therein), the first magmatic events occurred during the 104 Paleocene-Eocene in the westernmost districts (Val d'Adige and Lessini Mts.), and only in the 105 Oligocene-Miocene in the easternmost districts (Berici Hills, Euganean Hills, and Marostica Hills). 106 However, the onset of the magmatism, generally ascribed to the Paleocene, is questionable as the age 107 was inferred only by stratigraphic evidence of submarine volcanic products described in past studies 108 (Barbieri, 1972; Medizza, 1965). The oldest radioisotopic age recorded in the VVP is $\sim 51 \mathrm{Ma}$ 109 (Eocene), which results from some zircons hosted in a basanite of the Lessini Mts. analyzed by Visonà 110 et al. (2007). This dating is discarded in this work, as the relative data are not concordant and the 111 zircons were not crystallized directly from the erupted magma (see Brombin et al., 2019 for a review).

112 From the petrographic and petrological point of view, VVP magmatic products are basalts sensu lato $113\left(\mathrm{SiO}_{2}<55\right.$ wt.\%, $\mathrm{MgO}>6$ wt.\%; Wilson and Downes, 2006), ranging in composition from highly 114 alkaline products that are strongly silica under-saturated (nephelinites) to alkaline (basanites and 115 alkaline basalts) and subalkaline (tholeiitic basalts) magmatic products (Beccaluva et al., 2007; 116 Macera et al. 2003). Only in the Euganean Hills, more differentiated magmatic products, such as 117 rhyolites, trachytes, and subordinate latites are also present (Milani et al., 1999). Although previous 118 studies already tried to relate VVP petrological and geochronological data to the geodynamic 119 framework, more research is necessary to establish a clear causal link between the timing of 120 volcanism and the nature of the related magmas with the tectonic processes occurring at a regional 121 scale.

\section{3. Material and methods}

$124 \quad 3.1$ Sampling

125 For this study, four samples were collected in the Lessini Mts. and Val d'Adige districts (Fig. 1), i.e., 126 the westernmost and plausibly oldest VVP occurrences (Brombin et al., 2019 and reference therein). 127 In particular, two samples were collected from the central portion of Lessini Mts.: BS1 was collected 
in a quarry of columnar basalts in the town of San Giovanni Ilarione and BS3 in a lava flow near the

129 famous Bolca Fossil-Lagerstätte area (Papazzoni et al., 2014, and references therein). Two samples were collected from Val d'Adige: BS6 was sampled in a basaltic lava flow of the Northeastern part of Monte Baldo and BS7 in a volcanic neck near the town of Rovereto. Another four samples were also collected South- and East-ward in the Marostica Hills and Berici Hills (Fig. 1), as these districts are still scarcely investigated and poorly constrained in age. For Marostica Hills, two samples were collected: BS10 is from the western border of the district and VB1 is from the volcanic neck of Monte Gloso, which cut the middle Oligocene marine sediments. In the Berici Hills, almost all the magmatic products are covered by the overlain marine sediments, and the two samples of this study (VB3 and VB4) were collected from intruded sills in the Southwestern edge of this district.

\subsection{Analytical methods}

After removal of visibly weathered material, samples were cut for the preparation of thin sections that were investigated at the optical microscope. For each sample, the proportions of phenocrysts and matrix (i.e., microlites and glass) were determined by point counting on thin section $(\sim 1000$ point per sample). The samples were analyzed for the major-element compositions of minerals using a CAMECA SX 50 electron microprobe (EMP) at the CNR "Istituto di Geologia Ambientale e Geoingegneria" laboratories of the University of Rome "La Sapienza" (Italy). Analytical conditions were as follows: $15 \mathrm{kV}$ acceleration potential; beam size focused at $5 \mu \mathrm{m} ; 15 \mathrm{nA}$ beam current; 2030 seconds counting time, as a function of the analyzed element. Silicate minerals and synthetic oxides were employed as standards.

Other sample aliquots were crushed, and fresh chips were powdered using an agate ring mill. Wholerock major and trace elements of samples were determined by Wavelength Dispersive X-Ray Fluorescence Spectrometry (WDXRF) on pressed powder pellets at the Department of Physics and Earth Sciences, University of Ferrara (Italy), using an ARL Advant-XP spectrometer. Accuracy is estimated on the basis of repeated analyses of standards, generally lower than $2 \%$ for major oxides 
and less than $5 \%$ for trace element determinations, whereas the detection limits for trace elements range from 1 to $2 \mathrm{ppm}$ (Supplementary table 1a). Volatile contents were determined as loss on ignition (LOI) at $1000{ }^{\circ} \mathrm{C}$.

For the determination of additional trace elements, sample powders were totally digested in PFA Savillex beakers with a mixture of $\mathrm{HF}$ and $\mathrm{HNO}_{3}$. Dissolved samples were dried out and then redissolved in $2 \% \mathrm{HNO}_{3}$. The analyses were performed at the Department of Earth Sciences, University of Florence (Italy) with an Agilent 7800 ICP-MS using Rh as internal standard and a multi-elemental standard solution for calibration (Inorganic Ventures, VA, USA). Accuracy and precision, calculated on the base of repeated analyses of samples and rock standards (AGV-1, BHVO-1, BCR-2) were better than $10 \%$ for all the analyzed elements (Supplementary table $1 \mathrm{~b}$ ).

The whole rock $\mathrm{Sr}$ and $\mathrm{Nd}$ isotopic compositions were determined at the Department of Earth Sciences, University of Florence. Sample powders were preliminarily leached with $1 \mathrm{~N} \mathrm{HCl}(e . g$., for 1 hour in an ultrasonic bath and rinsing with Milli-Q water) before the $\mathrm{HF}-\mathrm{HNO}_{3}-\mathrm{HCl}$ acid digestion. Sr and Nd purification has been carried out using standard chromatographic techniques (e.g., Avanzinelli et al., 2005). Sr and Nd isotopes were measured by magnetic sector multi-collector ThermoFisher Triton-Ti Plus mass spectrometer in static mode and the effect of mass fractionation has been corrected using an exponential law to ${ }^{86} \mathrm{Sr} /{ }^{88} \mathrm{Sr}=0.1194$ and ${ }^{146} \mathrm{Nd} /{ }^{144} \mathrm{Nd}=0.7219$, respectively. Repeated analyses of NIST SRM 987 and a Nd internal standard (Nd-Fi) yielded ${ }^{87} \mathrm{Sr} /{ }^{86} \mathrm{Sr}=0.710256 \pm 5(2 \sigma, \mathrm{n}=3)$, and ${ }^{143} \mathrm{Nd} /{ }^{144} \mathrm{Nd}=0.511469 \pm 14(2 \sigma, \mathrm{n}=3)$ over the period of analyses. The $\mathrm{Nd}$ isotope composition of the internal standard Nd-Fi is referred to the La Jolla ${ }^{143} \mathrm{Nd} /{ }^{144} \mathrm{Nd}=0.511847 \pm 7(2 \sigma, \mathrm{n}=53)$. These values are in well agreement with the long-term reproducibility of the laboratory and with reference values. Total procedural blanks were well below $100 \mathrm{pg}$, so negligible with respect to the sample size.

177 Considering that major and trace elements ad $\mathrm{Sr}-\mathrm{Nd}$ isotopes were very homogeneous, $\mathrm{Pb}$ isotope 178 characterization was restricted on a subset of samples (BS1, BS3, BS6, BS7, and BS10). The Pb 179 isotope analyses were carried out at the Department of Earth Science of University of New Hampshire 
(USA). After powder sample digestion using a mixture of concentrated $\mathrm{HF}-\mathrm{HNO}_{3}, \mathrm{~Pb}$ was collected using techniques described by Bryce and DePaolo (2004). Isotopic measurements were performed on a Nu Plasma II ES Multi-Collector Inductively Coupled Plasma Mass Spectrometer (MC-ICP-MS), following procedures outlined in Bianchini et al. (2014). NIST SRM 981 aliquots were run as unknown samples, yielding averages (with $2 \sigma$ ) of ${ }^{208} \mathrm{~Pb} /{ }^{204} \mathrm{~Pb}=36.7282 \pm 0.0072,{ }^{207} \mathrm{~Pb} /{ }^{204} \mathrm{~Pb}=$ $15.4986 \pm 0.0023$ and ${ }^{206} \mathrm{~Pb} /{ }^{204} \mathrm{~Pb}=16.9416 \pm 0.0016$, all in close agreement with the values reported by Eisele et al. (2003). Total procedural blanks were in the order of $100 \mathrm{pg}$.

For geochronology both ${ }^{40} \mathrm{Ar} /{ }^{39} \mathrm{Ar}$ and $\mathrm{K} / \mathrm{Ar}$ methods were employed. The ${ }^{40} \mathrm{Ar} /{ }^{39} \mathrm{Ar}$ plateau ages are preferable with respect to $\mathrm{K} / \mathrm{Ar}$ ages because they are calculated by pooling the ages of several gas increments that can be cross checked. This type of analysis was specifically carried out on samples from the Val d'Adige and Lessini Mts., where previous studies identified the oldest VVP products, as we wanted to refine the information concerning the onset of the VVP magmatism that is still debated in the literature (see Brombin et al., 2019 for a review). Additional K/Ar analyses were carried out on samples from the Marostica and Berici Hills, just to verify if the spatial-temporal variation proposed by earlier papers is consistent. The geochronology analyses were performed using ${ }^{40} \mathrm{Ar} /{ }^{39} \mathrm{Ar}$ dating technique for samples BS1, BS3, BS6, BS7, and using the K/Ar dating technique for BS10, VB1, VB3, and VB4. As all samples are basic in composition and lack K-rich minerals suitable for geochronology, the dating analyses were performed on groundmass. Fresh chips of the samples were crushed with a rigorously cleaned steel hydraulic press, sieved to a size fraction of 250-500 $\mu \mathrm{m}$ and rinsed in distilled $\mathrm{H}_{2} \mathrm{O}$ and in an ultrasonic bath to remove any dust or powder. In order to collect only the sample grains constituted by the groundmass, the sample fractions were handpicked under a binocular microscope to remove any phenocrysts (pyroxene and olivine). For ${ }^{40} \mathrm{Ar} /{ }^{39} \mathrm{Ar}$ analyses, after the irradiation in the TRIGA Reactor at the Oregon State University (USA), sample groundmass was analyzed at the Noble Gas Lab of the University of Vermont (USA) by laser step-heating using a Nu Instruments Noblesse magnetic sector noble gas mass spectrometer linked to an ultrahigh-vacuum extraction line powdered by a Santa Cruz Laser Microfurnace $75 \mathrm{~W}$ diode laser system. Age plateaus 
are defined by three or more consecutive steps within uncertainty encompassing $60 \%$ or more of the

$207{ }^{39} \mathrm{Ar}$, and all ages are reported with $1 \sigma$ uncertainty. The K/Ar analyses were carried out at Actlabs in 208 Canada. The determination of radiogenic Ar content was carried out twice on MI-1201 IG mass209 spectrometer by isotope dilution method with ${ }^{38} \mathrm{Ar}$ as spike. Additional details about the 210 geochronological analyses are reported in the Supplementary material.

\section{Results}

\subsection{Rock classification, petrography, and mineral chemistry}

According to the total alkali vs. silica (TAS) diagram (Le Maitre et al., 2002; Fig. 2a) the samples range between ultrabasic to basic compositions, with a general alkaline affinity. Samples BS3, BS6, BS7, VB1, VB3, and VB4 are classified as basanites on the TAS diagram, and they are nephelinenormative (Supplementary table 2). They show porphyritic texture with euhedral/subhedral olivine (up to $2 \mathrm{~mm}$ across) and subordinate clinopyroxene (up to $0.5 \mathrm{~mm}$ across) as dominant phenocrysts set in a microcrystalline groundmass constituted by acicular plagioclase, clinopyroxene, and oxides (Fig. 3; Supplementary table 2). Sample BS1 is classified as basalt according the TAS diagram and it is nepheline-normative (Supplementary table 2). It is characterized by less and smaller olivine (up to $1 \mathrm{~mm}$ across) and clinopyroxene (up to $0.2 \mathrm{~mm}$ across) phenocrysts than those in basanites, within a groundmass including acicular plagioclase, clinopyroxene, oxides, and glass (Fig. 3a; Supplementary table 2). Sample BS10 is classified as basaltic trachyandesite in the TAS diagram (Fig. 2a) and is hypersthene-normative (Supplementary table 2). It is characterized by intergranular texture with elongated and euhedral plagioclase (up to $2 \mathrm{~mm}$ across) and subhedral clinopyroxene, olivine, and oxides filling spaces between plagioclase crystals (Fig. 3e; Supplementary table 2). The mineral compositions of olivine, clinopyroxene, and plagioclase are quite homogeneous among the sample population. The Fo $[100 \times \mathrm{Mg} /(\mathrm{Mg}+\mathrm{Fe}) \mathrm{mol}$, where $\mathrm{Fe}$ is total iron $]$ content of olivine phenocrysts of samples BS3, BS6, BS7, VB3, and VB4 range from 71.8 to 83.1; only VB1 has higher 231 Fo contents ranging from 82.6 to 88.7. The clinopyroxene crystals are all diopside, with Wo47-53 $\mathrm{En}_{32-}$ 
${ }_{41} \mathrm{Fs}_{10-15}$ and $\mathrm{Mg} \#\left[100 \times \mathrm{Mg} /(\mathrm{Mg}+\mathrm{Fe})_{\mathrm{mol}}\right.$, where $\mathrm{Fe}$ is total iron] varying from 69.4 to 80.2 , with no significant variation from core to rim. Only clinopyroxenes of VB1 have a composition slightly different (Wo45-47 $\mathrm{En}_{42-43} \mathrm{Fs}_{8-9}$ ) and higher Mg\# ( 82). For all samples, the microphenocrysts of plagioclase have an andesine composition $\left(\mathrm{An}_{49}\right.$ to $\left.\mathrm{An}_{64}\right)$. Noteworthy, samples BS1, BS3, VB1 and VB4 host small $(2-3 \mathrm{~cm})$ mantle peridotite xenoliths, similar to those described in other VVP sample suites (Beccaluva et al., 2001; Brombin et al., 2018; Gasperini et al., 2006; Morten et al., 1989; Siena and Coltorti, 1989, 1993).

\subsection{Geochemistry}

Whole rock major and trace element compositions are reported in Supplementary table 2. On the TAS diagram the investigated samples have $\mathrm{SiO}_{2}$-alkali contents similar to the other VVP rocks having a relatively primitive character (Beccaluva et al., 2007; Brombin et al., 2019; Macera et al., 2003; Milani et al., 1999; Fig. 2a). In fact, samples of this study have low $\mathrm{SiO}_{2}$ (42.6 to 51.2 wt.\%), high $\mathrm{MgO}$ (12.4 to 7.7 wt.\%) contents, and high Mg\# (67.8 to 57.2, Supplementary table 2). The samples have alkaline compositions, except for BS10, which straddles alkaline and subalkaline fields in the TAS diagram. The samples BS3, BS7, BS10, VB1, VB3, and VB4 have sodic character $\left[\left(\mathrm{Na}_{2} \mathrm{O}-\right.\right.$ $\left.\mathrm{K}_{2} \mathrm{O}\right) \geq 2.0$ wt. $\%$ ] with $\left(\mathrm{Na}_{2} \mathrm{O}-\mathrm{K}_{2} \mathrm{O}\right)$ ranging from 2.03 wt. $\%$ to 3.89 wt.\%, while samples $\mathrm{BS} 1$ and BS6 show a slight potassic affinity, as $\left(\mathrm{Na}_{2} \mathrm{O}-\mathrm{K}_{2} \mathrm{O}\right)$ values are 1.82 wt.\% and 1.49 wt.\%, respectively. Compatible trace elements have relatively high concentration with Ni varying from 102 to $310 \mathrm{ppm}$, Co from 42 to $76 \mathrm{ppm}$, Cr from 170 to $432 \mathrm{ppm}$, V from 159 to $298 \mathrm{ppm}$, which confirm that samples are relatively undifferentiated (Supplementary table 2).

In terms of incompatible trace elements, the samples of this study overlap with the VVP rocks investigated in literature (Beccaluva et al., 2007; Brombin et al., 2019; Macera et al., 2003; Milani et al., 1999). The primordial mantle-normalized (McDonough and Sun, 1995) incompatible trace element patterns of basanites (BS3, BS6, BS7, VB1, VB3, VB4) and basalt (BS1), are nearly parallel (Fig. 2b). These samples display Light (L-) Rare Earth Element (REE) enrichment and a LREE to 
258 Heavy $(\mathrm{H}-)$ REE fractionation $\left[(\mathrm{La} / \mathrm{Yb})_{\mathrm{N}}: 14.22\right.$ - 23.37; $(\mathrm{Dy} / \mathrm{Lu})_{\mathrm{N}}: 2.19$ - 2.86; Fig. 2b]. They also 259 exhibit negative $\mathrm{K}, \mathrm{Rb}, \mathrm{Zr}$, $\mathrm{Hf}$, and $\mathrm{Ti}$ anomalies as well as positive $\mathrm{Ba}$ and $\mathrm{P}$ anomalies.

260 The basaltic trachyandesite (BS10), i.e., the least alkaline rock of this sample suite, mimics - at lower 261 concentration - the general trace element pattern of other VVP rocks, showing a steeper negative 262 slope from $\mathrm{Nb}$ to $\mathrm{Y}$ and the lack of positive $\mathrm{Ba}$ and negative $\mathrm{Rb}$ anomalies (Fig. $2 \mathrm{~b}$ ).

263 The $\mathrm{Sr}-\mathrm{Nd}-\mathrm{Pb}$ isotopic ratios are listed in Table 1. 
Table 1. $\mathrm{Sr}, \mathrm{Nd}, \mathrm{Pb}$ isotope composition of VVP samples.

265

\begin{tabular}{|c|c|c|c|c|c|c|c|c|}
\hline \multirow[b]{2}{*}{ Sample } & \multicolumn{3}{|c|}{ Lessini Mts. } & \multicolumn{2}{|c|}{ Val d'Adige } & \multirow{2}{*}{$\frac{\text { Marostica Hills }}{\text { VB1 }}$} & \multicolumn{2}{|c|}{ Berici Hills } \\
\hline & BS1 & BS3 & BS10 & BS6 & BS7 & & VB3 & VB4 \\
\hline Rock & Basalt & Basanite & $\begin{array}{c}\text { Basaltic } \\
\text { trachyandesite }\end{array}$ & Basalt & Tephrite & Basanite & Basanite & Basanite \\
\hline${ }^{143} \mathrm{Nd} /{ }^{144} \mathrm{Nd}$ & $0.512942 \pm 5$ & $0.512927 \pm 5$ & $0.512934 \pm 6$ & $0.512917 \pm 7$ & $0.512912 \pm 4$ & $0.512927 \pm 4$ & $0.512930 \pm 4$ & $0.512935 \pm 4$ \\
\hline${ }^{87} \mathrm{Sr} /{ }^{86} \mathrm{Sr}$ & $0.703250 \pm 6$ & $0.703192 \pm 6$ & $0.703303 \pm 5$ & $0.703295 \pm 6$ & $0.703234 \pm 6$ & $0.703283 \pm 6$ & $0.703222 \pm 6$ & $0.703212 \pm 7$ \\
\hline${ }^{206} \mathrm{~Pb} /{ }^{204} \mathrm{~Pb}$ & 19.4231 & 19.5683 & 19.4314 & 19.4295 & 19.4900 & - & - & - \\
\hline${ }^{207} \mathrm{~Pb} /{ }^{204} \mathrm{~Pb}$ & 15.6555 & 15.6588 & 15.6562 & 15.6658 & 15.6623 & - & - & - \\
\hline${ }^{208} \mathrm{~Pb} /{ }^{204} \mathrm{~Pb}$ & 39.2655 & 39.3303 & 39.2688 & 39.2725 & 39.3332 & - & - & - \\
\hline
\end{tabular}


268 The VVP magmatic products of this study are characterized by $l o w{ }^{87} \mathrm{Sr} /{ }^{86} \mathrm{Sr}(0.70319-0.70330$; Fig. $2694 \mathrm{a}, \mathrm{b})$ and high ${ }^{143} \mathrm{Nd} /{ }^{144} \mathrm{Nd}(0.512912$ - 0.512942; Fig. 4a, b) ratios, which fall into the isotopic ranges 270 of the majority of VVP basic-ultrabasic magmatic products studied in literature ${ }^{87} \mathrm{Sr} /{ }^{86} \mathrm{Sr}: 0.70315-$ $271 \quad 0.70386 ;{ }^{143} \mathrm{Nd} /{ }^{144} \mathrm{Nd}$ : 0.51285 - 0.51298; Beccaluva et al., 2007; Macera et al., 2003; Fig. 4a, b).

272 The $\mathrm{Pb}$ isotopes exhibit a narrow variability $\left({ }^{206} \mathrm{~Pb} /{ }^{204} \mathrm{~Pb}: 19.423-19.568 ;{ }^{207} \mathrm{~Pb} /{ }^{204} \mathrm{~Pb}: 15.656-\right.$ $27315.666 ;{ }^{208} \mathrm{~Pb} /{ }^{204} \mathrm{~Pb}: 39.266$ - 39.333; Fig. 4c-f), included in the compositional range described by 274 previous authors $\left({ }^{206} \mathrm{~Pb} /{ }^{204} \mathrm{~Pb}: 18.786-19.760 ;{ }^{207} \mathrm{~Pb} /{ }^{204} \mathrm{~Pb}: 15.580-15.670 ;{ }^{208} \mathrm{~Pb} /{ }^{204} \mathrm{~Pb}: 38.807\right.$ 275 39.490; Beccaluva et al., 2007; Macera et al., 2003; Fig. 4c-f). In Pb-Pb spaces (Fig. 4c-f), the VVP 276 samples of this study define a linear trend above the Northern Hemisphere Reference Line (NHRL; 277 Hart, 1984). In particular, in the ${ }^{206} \mathrm{~Pb} /{ }^{204} \mathrm{~Pb} v{ }^{207} \mathrm{~Pb} /{ }^{204} \mathrm{~Pb}$ plot (Fig. 4c, d) the basanites (BS3, BS6, 278 BS7) define a perpendicular trend above the NHRL with the BS3 and BS6, as the nearest and the 279 furthest samples from the NHRL, respectively. The basalt (BS1) and the basaltic trachyandesite 280 (BS10) are off this trend, having lower ${ }^{207} \mathrm{~Pb} /{ }^{204} \mathrm{~Pb}$ values (15.655 - 15.656; Table 1) with respect to 281 the remaining samples of the suite $(15.658-15.665$; Table 1$)$. In the ${ }^{206} \mathrm{~Pb} /{ }^{204} \mathrm{~Pb}$ vs ${ }^{208} \mathrm{~Pb} /{ }^{204} \mathrm{~Pb}$ plot 282 (Fig. 4e, f), BS1, BS6, BS7, and BS10 define a parallel trend above the NHRL, only sample BS3 is 283 off this trend, plotting just off the NHLR.

\section{3. ${ }^{40} \mathrm{Ar}{ }^{39} \mathrm{Ar}$ and $\mathrm{K} / \mathrm{Ar}$ geochronological constraints}

286 In order to date the oldest VVP districts (i.e., Lessini Mts. and Val d'Adige), samples BS1, BS3, BS6, 287 and BS7 were subjected to ${ }^{40} \mathrm{Ar} /{ }^{39} \mathrm{Ar}$ dating. The results of the analyzed VVP samples and the 288 estimated ages are reported in Table 2. 
Table 2. Summary of ${ }^{40} \mathrm{Ar} /{ }^{39} \mathrm{Ar}$ results for VVP samples.

\begin{tabular}{|c|c|c|c|c|c|c|c|c|c|}
\hline & & \multicolumn{3}{|c|}{ Isochron characteristics } & \multicolumn{5}{|c|}{ Plateau characteristics } \\
\hline & & $\begin{array}{c}\text { Inverse } \\
\text { isochron age } \\
(\mathrm{Ma}, \pm 2 \sigma)\end{array}$ & $\begin{array}{c}{ }^{40} \mathrm{Ar} /{ }^{36} \mathrm{Ar} \\
\text { intercept } \\
( \pm 2 \sigma)\end{array}$ & MSWD & $\begin{array}{c}\text { Plateau age } \\
(\mathrm{Ma}, \pm 2 \sigma)\end{array}$ & $\begin{array}{c}\text { Total } \\
{ }^{39} \mathrm{Ar} \\
\text { released } \\
(\%)\end{array}$ & $\mathrm{p}$ & MSWD & $\mathrm{n}(\mathrm{N})$ \\
\hline \multicolumn{10}{|l|}{ Lessini Mts. } \\
\hline BS1 & Basalt & $44.4 \pm 10.4$ & $299 \pm 64$ & 4.9 & $42.76 \pm 1.70$ & 60 & 0.10 & 1.9 & $5(10)$ \\
\hline $\begin{array}{l}\text { BS3 } \\
\text { (first test) }\end{array}$ & Basanite & 45.9 & 125 & 2.4 & \multicolumn{5}{|c|}{ No plateau age } \\
\hline $\begin{array}{l}\mathrm{BS} 3 \\
\text { (second test) }\end{array}$ & Basanite & 43 & 164 & 65.0 & \multicolumn{5}{|c|}{ No plateau age } \\
\hline \multicolumn{10}{|l|}{ Val d'Adige } \\
\hline BS6 & Basanite & $41.9 \pm 2.0$ & $282 \pm 38$ & 0.7 & $41.73 \pm 0.84$ & 97 & 0.07 & 2.2 & $5(6)$ \\
\hline BS7 & Basanite & $42.8 \pm 3.0$ & $182 \pm 100$ & 7.4 & $41.21 \pm 1.76$ & 92 & 0.00 & 5.3 & $8(9)$ \\
\hline
\end{tabular}

Almost all inverse isochrons yielded ${ }^{40} \mathrm{Ar} /{ }^{36} \mathrm{Ar}$ intercepts similar to the atmospheric value $(298.56 \pm$

0.31; Lee et al., 2006), indicating that the analyzed rocks did not have trapped excess argon. For the

Lessini Mts. samples, the basalt BS1 has a ${ }^{40} \mathrm{Ar} /{ }^{36} \mathrm{Ar}$ intercepts indistinguishable from the atmospheric ratio (299 \pm 64 ; Fig. 5a) and yielded a mini-plateau age of $42.76 \pm 1.70 \mathrm{Ma}$ [mean square weighted deviation $(\mathrm{MSWD})=1.9$; probability $(\mathrm{p})=0.10$; Fig. $5 \mathrm{~b})$, as it based on $60 \%$ of the total gas. For the basanite $\mathrm{BS} 3$, the geochronological analysis was repeated twice, as the first analysis did not result in a plateau age; however, in the first test the maximum apparent age of the steps was $\sim 45 \mathrm{Ma}$ (Fig. $5 \mathrm{~d}$ ) as confirmed by the inverse isochron age (Fig. 5c). In the second test the maximum apparent age of the steps was $\sim 43 \mathrm{Ma}$ (Fig. 5f), again confirmed by the respective inverse isochron age (Fig. 5e), indicating that the apparent age of this sample is between 43 and $45 \mathrm{Ma}$. For this sample we are more prone to consider the oldest age ( $\sim 45 \mathrm{Ma})$ more valid, rather than the youngest age ( $43 \mathrm{Ma})$, as the corresponding inverse isochron has the lowest error (Fig. 5c); additionally, another basanite collected in the same locality was analyzed by Brombin et al. (2019) and yielded both plateau age and inverse isochron age of $45 \mathrm{Ma}$. For the Val d'Adige samples: the basanite BS6 is characterized by a ${ }^{40} \mathrm{Ar} /{ }^{36} \mathrm{Ar}$ intercept indistinguishable from the atmospheric ratio $(282 \pm 38$; Fig. $5 \mathrm{~g})$, which results in a 
311 calculated plateau age of $41.73 \pm 0.84 \mathrm{Ma}(\mathrm{MSWD}=2.2 ; \mathrm{p}=0.07$; Fig. $5 \mathrm{~h})$ accounting for $90 \%$

312 released ${ }^{39} \mathrm{Ar}$. For the basanite BS7 the ${ }^{40} \mathrm{Ar} /{ }^{36} \mathrm{Ar}$ intercept was sub-atmospheric (182 $\pm 100 ;$ Fig. 5i),

313 indicating argon loss probably due to the alteration. Its apparent age spectra yielded a plateau age of

$31441.21 \pm 1.76 \mathrm{Ma}(\mathrm{MSWD}=5.3$; Fig. $5 \mathrm{j})$ including $90 \%$ of the released ${ }^{39} \mathrm{Ar} .$.

315 The data set was integrated with additional K/Ar geochronological data on samples BS10, VB1, VB3,

316 and VB4 (Table 3), constraining the timeframe of magmatic activities occurred in Berici Hills and

317 Marostica Hills districts, which although are poorly investigated by previous studies, was considered 318 younger with respect to those of the Lessini area.

Table 3. Summary of K/Ar results for VVP samples.

\begin{tabular}{|c|c|c|c|c|}
\hline & & $\begin{array}{c}\mathrm{K} \\
(\% \pm 2 \sigma)\end{array}$ & $\begin{array}{c}{ }^{40} \mathrm{Ar} \text { radiogenic } \\
(\mathrm{ng} / \mathrm{g})\end{array}$ & $\begin{array}{c}\text { Age } \\
(\mathrm{Ma}, \pm 2 \sigma)\end{array}$ \\
\hline \multicolumn{5}{|c|}{ Marostica Hills } \\
\hline BS10 & Basaltic trachyandesite & $1.17 \pm 0.02$ & $2.66 \pm 0.03$ & $32.5 \pm 1.2$ \\
\hline VB1 & Basanite & $0.694 \pm 0.010$ & $1.294 \pm 0.009$ & $26.7 \pm 0.8$ \\
\hline
\end{tabular}

Berici Hills

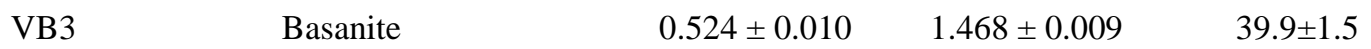

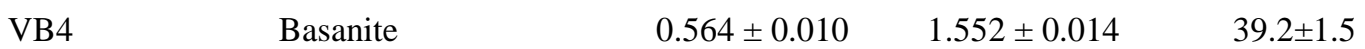

321 Potassium concentration in percent, radiogenic argon in ng/g. Ages (Ma) analytical uncertainties are quoted at 2 sigma $322(2 \sigma)$ confidence levels.

For the Marostica Hills, the basaltic trachyandesite BS10 collected in the western edge of the district recorded an age of $32.5 \pm 1.2 \mathrm{Ma}$, and the basanite VB1 from the neck of Monte Gloso yielded an age of $26.7 \pm 1.5 \mathrm{Ma}$. The latter age tends to that reported in literature by Brombin et al. (2019), which dated other two samples from the same location and obtained ${ }^{40} \mathrm{Ar} /{ }^{39} \mathrm{Ar}$ ages of $\sim 22 \mathrm{Ma}$. For the Berici Hills the two basanites VB3 and VB4 yielded indistinguishable ages of $39.9 \pm 1.5$ and $39.2 \pm 1.5 \mathrm{Ma}$, respectively.

\section{Discussion}


334 Despite the fact that the VVP magmatism was distributed in five magmatic districts over an area of $335 \sim 1500 \mathrm{~km}^{2}$ in the southeastern Alpine domain, the magmatic products show a consistent intraplate 336 character, as well as very homogeneous trace element and isotopic features (Figs. 2b, 4). In addition, 337 the mineral compositions of olivines, clinopyroxenes, and plagioclases are also homogenous across 338 our sample suite, emphasizing that the VVP districts share similar parental melts, and plausibly 339 mantle source(s) and melting conditions. The VVP samples frequently entrain mantle xenoliths, thus 340 indicating a rapid ascent from the mantle source region, without stagnation in crustal magma 341 chambers. This hypothesis is corroborated by the small difference (a few tens of ${ }^{\circ} \mathrm{C}$ ) between the 342 temperature at which VVP melts were segregated from the mantle, which is $1370{ }^{\circ} \mathrm{C}$ on average, 343 according to the algorithm defined by Albaréde (1992), and the olivine liquidus temperature 344 extrapolated by the Roeder and Emslie (1970) geothermometer. Coherently, the trace element 345 patterns and positive and negative anomalies of the VVP samples should be interpreted as features 346 inherited by mantle sources, considering the primitive character of the rocks. In Fig. $2 \mathrm{~b}$, the patterns 347 are similar to the Ocean Island Basalt (OIB; Sun and McDonough, 1989) trend and consistent with 348 the intraplate features already noticed in previous studies (Beccaluva et al., 2007; Brombin et al., 349 2019; Macera et al., 2003; Milani et al., 1999). Based on trace elements, Beccaluva et al. (2007) 350 invoked as potential source a spinel lherzolite enriched by hydrated-carbonated components. On the 351 contrary, Brombin et al. (2019) proposed a garnet lherzolite possibly metasomatized by carbonatitic 352 melts and with residual phlogopite as a potential source, which is more consistent with the trace 353 element patterns observed from the samples of this study. In fact, VVP products exhibit the steep 354 Middle (M-) HREE profiles typical of a garnet signature, as well as $\mathrm{K}$, Rb depletions indicating a $\mathrm{K}$ 355 ( $\mathrm{Rb}$ )-bearing residual phase, like phlogopite or amphibole, in the mantle source (e.g., Moine et al., 356 2001) (Fig. 2b). According to LaTourette et al. (1995), melts formed from amphibole-bearing 357 peridotites have higher $\mathrm{Ba} / \mathrm{Rb}$ ratio $(>50)$ than melts of a phlogopite-bearing peridotites $(\mathrm{Ba} / \mathrm{Rb}<$ 358 20). Most VVP samples exhibit low $\mathrm{Ba} / \mathrm{Rb}$ values (10 to 20), which indicate the presence of residual 
phlogopite within their mantle source. Only Berici Hills basanites (VB3 and VB4) show very high

$360 \mathrm{Ba} / \mathrm{Rb}$ ratios (> 100), which suggest a mantle source with amphibole rather than phlogopite as residual 361 phase. However, despite the possible mineralogical differences in the relative mantle sources, all VVP samples are invariably characterized by $\mathrm{Ba}$ and $\mathrm{P}$ enrichments, which recall metasomatism by carbonatitic fluids (Merle et al., 2017).

In order to investigate further the possible nature of the VVP mantle source, the $\mathrm{Sr}, \mathrm{Nd}$, and $\mathrm{Pb}$ isotopes presented in this study were compared with those previously reported in the literature (Beccaluva et al., 2007; Macera et al., 2003). The analyzed VVP samples are characterized by low ${ }^{87} \mathrm{Sr} /{ }^{86} \mathrm{Sr}$ and high ${ }^{143} \mathrm{Nd} /{ }^{144} \mathrm{Nd}$ isotopic ratios that are consistent with the previous investigations (Beccaluva et al., 2007; Macera et al., 2003; Milani et al., 1999; Fig. 4a, b). Only few samples from Lessini Mts. and Euganean Hills from the literature record higher ${ }^{87} \mathrm{Sr} /{ }^{86} \mathrm{Sr}$ (up to 0.70386) and lower ${ }^{143} \mathrm{Nd} /{ }^{144} \mathrm{Nd}$ (up to 0.51285 ) isotopic compositions, due to sporadic shallow level crustal contamination during magma upraising and emplacement (Macera et al., 2003). In the Sr-Nd diagram, all samples of our suite are close to the HIMU mantle, and cluster near the EAR (European Asthenospheric Reservoir; Cebriá and Wilson, 1995; Hoernle et al., 1995; Wilson and Downes, 2006). The $\mathrm{Pb}$ isotopic ratios confirm this fingerprint, as the VVP samples plotted between DMM and HIMU components, and also in this case are near the EAR. The EAR is a regional sublithospheric mantle component extending from the eastern Atlantic to Europe and the Mediterranean area (Bianchini et al., 1999; Wilson and Bianchini, 1999), which is also known in literature as the low-velocity component (LVC; Hoernle et al., 1995), or Common Mantle Reservoir (CMR; Lustrino and Wilson, 2007). The EAR was invoked for other intraplate Late Cretaceous-Cenozoic magmatic 380 occurrences from the Adria microplate, such as the Pietre Nere and Mount Queglia dikes (Bianchini 381 et al., 2008). The Sr-Nd-Pb isotopic fingerprint of VVP rocks, approaching those of other intraplate magmatic districts of the Mediterranean area, indicates that the VVP mantle sources were unaffected 383 by the Cenozoic subduction-related processes which occurred in the Alpine domain (Bianchini et al., 384 2008; Wilson and Bianchini, 1999). There are several cases worldwide documenting the presence of 
intraplate-like magmatism near subduction zones (especially in the circum-Mediterranean area;

386 Beccaluva et al., 2011), and the geodynamic interpretations are various and still matter of debate in 387 the geological literature. In the following section we present a new geodynamic model inferred by 388 the timing of the VVP intraplate magmatic activities and the coeval magmatic orogenic activities 389 along the Periadriatic line.

5.2. Temporal and volume distribution of VVP magmatic activities: constraints for a new geodynamic model

According to the temporal reconstruction of the VVP provided by the past studies, the magmatism occurred intermittently for a very long period ( $40 \mathrm{My})$, starting from the Paleocene in the Lessini Mts. and Val d'Adige districts (Barbieri, 1972; Medizza 1965) and then migrating East (Bassi et al., 2008; Brombin et al., 2019; De Vecchi and Seda, 1995). During the middle Eocene magmatic activity still occurred in the Lessini Mts. and Val d'Adige districts and started in the Berici Hills district. In the late Eocene, basic magmatism occurred in the Euganean Hills, while during the Oligocene differentiation processes become preponderant and produced acidic products. At this time, the magmatism started also in the Marostica Hills, where it likely continued until the Miocene (Bassi et 401 al., 2008; Brombin et al., 2019; De Vecchi and Sedea, 1995). In this study, for the first time, radioisotopic ages of samples collected in the Berici Hills testify the occurrence of magmatic activities during middle Eocene in this district. In addition, the K/Ar ages of samples collected in the Marostica Hills: i) verify the occurrence of magmatism in the Oligocene at least in the western border of this district and ii) confirm also the presence of magmatic events in the Miocene, as tentatively proposed by Brombin et al. (2019). The ${ }^{40} \mathrm{Ar} /{ }^{39} \mathrm{Ar}$ radioisotopic ages carried out in this work $408 \sim 42 \mathrm{Ma}$, respectively. Therefore, combining the recent ${ }^{40} \mathrm{Ar} /{ }^{39} \mathrm{Ar}$ dating from Brombin et al. (2019) 409 with those from this study, the oldest magmatism occurred in the Lessini Mts. can be dated to $\sim 45$ $410 \mathrm{Ma}$, at the latest. This suggests that the onset of the VVP magmatism was in the middle Eocene, and 
411 not in the Paleocene. Thus, the time-span of the VVP magmatism was much shorter than what 412 previously hypothesized in the literature only on the basis of stratigraphic evidence recorded in the 413 1960s and 1970s (Barbieri, 1972; Medizza 1965) without an independent confirmation by new 414 biostratigraphic and/or radioisotopic geochronological constraints.

415 According to the literature, the Eocene magmatism in Lessini Mts. and Val d'Adige districts 416 corresponds with the most intense VVP magmatic pulse, as the highest volumes of the VVP products 417 erupted in this zone. In order to test this interpretation, which is fundamental for the geodynamic 418 reconstruction of the mechanism responsible of the VVP magmatism, we estimated the volume of 419 magmas of each VVP district. For the calculation we used an approach similar to that of Svensen et 420 al. (2017), which estimated the sill volumes of Central Atlantic Magmatic Province. For this 421 calculation we measured the aerial extent of the present-day magmatic outcrops of each VVP district and the average thickness of volcanic formation reported in field observations and stratigraphic columns (Brombin et al., 2019). We determined the volumes of magmatic products hosted in Lessini Mts., Euganean Hills, and Marostica Hills districts (Fig. 6a; Supplementary table 3), while we did not perform the calculation for Val d'Adige and Berici Hills districts, where the aerial extents are totally subordinate. According to Fig. 6a, the amount of the magmatic products decreases in the VVP following the order Lessini Mts. > Euganean Hills > Marostica Hills, which suggests that the volume of magmas decreases towards East and also for the youngest VVP districts. Therefore, the paroxysm of the VVP magmatism occurred in the Eocene in the Lessini Mts., as the estimated volume of magmatic products is $36 \mathrm{~km}^{3}$ (Fig. 6a; Supplementary table 3) and then it waned toward the East 431 during Oligocene and Miocene, when eruptions occurred in Euganean Hills and Marostica Hills 432 districts, where we estimated 25 and $8.4 \mathrm{~km}^{3}$ of magmatic products, respectively (Fig. 6a; 433 Supplementary table 3).

434 Interestingly, the climax of VVP activity in the Eocene was nearly contemporaneous with the 435 emplacements of magmatic orogenic intrusive bodies along the Periadriatic lineament, in particular 436 those close to the Giudicarie fault system, as shown by the Adamello intrusive complex emplaced at 
43 Ma (Ji et al., 2019; Schaltegger et al., 2019; Fig. 6a), when Alpine subduction and continental

438 collision was still ongoing, as demonstrated by the existence of eclogitic units formed in the same 439 period (peak metamorphic age: 45-40 Ma Lapen et al., 2007; Malusà et al., 2011; Rubatto et al., 440 1998; Rubatto and Hermann, 2001; Wiederkehr et al., 2009).

441 Several authors have tried to explain the peculiar geodynamic framework which led to the occurrence 442 of intraplate magmas in the VVP in proximity of a subduction zone during the general Alpine 443 convergence. Among the distinct theories, the VVP was interpreted as a "passive impactogenic rift" 444 (Barberi et al., 1982; Mats and Perepelova, 2011), where activation of transtensional lineaments and 445 decompressional melting occurred as foreland reactions to the general Alpine convergence 446 (Beccaluva et al., 2007; 2011). Other interpretations favoured magma genesis induced by mantle 447 uprising through a slab window after the European slab breakoff (Macera et al., 2003). In their recent 448 study, Brombin et al. (2019) discarded the slab breakoff as the triggering mechanism of magma 449 genesis considering recent tomographic images and geophysical data, which evidenced a continuous nearly vertical slab, beneath the northern edge of the South Alpine region (Hua et al., 2017; Kästle et al., 2020; Zhao et al., 2016). According to plate-tectonic reconstructions of Handy et al. (2010, 2015) based on stratigraphic, petrological, geochronological data and seismic tomography, the slab beneath 453 the Alpine region was nearly vertical since $67 \mathrm{Ma}$, i.e., before the onset of the VVP magmatism. The presence of a poloidal mantle flow bypassing the Alpine slab deepening southward was thus suggested, providing the upraise of deep mantle domains unaffected by subduction-related fluids 456 beneath the South Alpine region (Brombin et al., 2019). The last model does not imply a horizontal 457 slab breakoff as proposed by Davies and von Blanckenburg (1995) and Macera et al. (2003) but 458 requires a "vertical" segmentation of the European slab in distinct sectors that are divided by 459 important translithospheric discontinuities that offset the Alpine belt. The hypothesis is compatible 460 with the most recent interpretations of the Alpine architecture based on geophysical data (Hua et al., 461 2017; Kästle et al., 2020; Zhao et al., 2016), which emphasized a sharp translithospheric discontinuity 462 (possibly a vertical slab tear) at the boundary between Central and Eastern Alps. In our view (Fig. 
$6 b)$, to reconcile the location of most orogenic magmatism along the Periadriatic lineament, which is

464 concentrated in the Adamello complex, and the VVP intraplate magmatism, the vertical slab tear 465 should be located in correspondence of the Giudicarie fault zone, and according to the magmatic 466 timing, its rupture plausibly occurred in the middle Eocene. This agrees with what suggested by 467 Castellarin et al. (2006) that emphasized a deep continuation of the Giudicarie lineament and its long468 lived activity.

469 In the lithospheric region, the vertical split between the two slab segments allowed the upwelling of 470 a deep poloidal asthenospheric mantle flow, whereas the deep lithospheric region near the slab was 471 likely affected by subduction-related fluids (Fig. 6b). Then, the poloidal mantle flow triggered the 472 partial melting in the mantle source(s) near the subduction slab, producing the orogenic (fluid473 dominated?) signature that characterized the Adamello magmatic products (Fig. 6b). The 474 asthenospheric poloidal mantle flow migrated toward East following the general eastward mantle 475 flow (Ficini et al., 2017; Petrescu et al 2020) and triggered the decompressional melting of the VVP mantle source, which remained unaffected by the subduction-related fluids due to its position far from the slab (Fig. 6b) and developed the observed intraplate signature. Therefore, the Giudicarie fault system represents the surface expression of an important lithospheric discontinuity activated in the middle Eocene. This discontinuity could be responsible for triggering orogenic magmatism in the Eocene along the Periadriatic Line, at least in the Central Alps domain (e.g., Adamello complex), and the synchronous intraplate magmatism in the western VVP districts (Lessini Mts. and Val d'Adige). After the main magmatic pulse during middle Eocene in the Lessini sector, the volcanism migrated eastward and southeastward in the Euganean and Marostica Hills, where magma genesis resumed in 484 the Oligocene and Miocene times, respectively. This spatio-temporal evolution of the volcanism is possibly related to the mantle poloidal flow, which transferred fertile mantle domains at velocity between 0.5 and $1 \mathrm{~cm} \mathrm{y}^{-1}$, estimated considering the distance between Lessini Mts. and Euganean/Marostica Hills districts and the time elapsed between the respective eruptions. This velocity estimate of the lateral mantle flow in subduction systems is of the same order of what was 
proposed by Funiciello et al. (2004) on the basis of 3D laboratory experiments. Noteworthy, the

490 importance of slab tears in controlling a) convective mantle cells around slabs and b) triggering of 491 magmatic occurrences variously influenced (or even not influenced) by subduction related fluids has 492 been convincingly proposed by Faccenna et al. (2007). Such process seems to be effective to explain 493 the Cenozoic spatio-temporal association of volcanic products having distinct magmatic affinity in 494 and around the Italian peninsula (e.g., Southern Tyrrhenian, Sicily; Bianchini et al., 2008; De Ritis et 495 al., 2019; Barreca et al., 2020), as well as to explain the occurrence of post-collisional intraplate magmatism in other areas of the world, e.g., in the Western Anatolia (Dilek and Altunkaynak, 2009; Prelević et al., 2015) and East Carpathian (Bracco Gartner et al., 2020).

\section{Conclusions}

500 The Veneto Volcanic Province (VVP) magmatic products in the Southeastern Alpine domain exhibit a geochemical and isotopic intraplate signature despite the nearby subduction-related magmatism that occurred along the Alpine belt as a consequence of the Europe-Adria convergence. The trace element patterns of the investigated VVP magmatic products point to a garnet-peridotite mantle source affected by carbonatitic fluids that stabilized metasomatic phases such as phlogopite or amphibole. According to the $\mathrm{Sr}-\mathrm{Nd}-\mathrm{Pb}$ isotopic analyses, the VVP lavas also have similar features to those of other Cenozoic intraplate magmatic provinces of the Adria microplate, whose mantle sources were ascribed to the European Asthenospheric Reservoir, with no evidence of subduction-related fluid contamination.

509 Because of the complexity of the geophysical data and tomographic images of the Alpine architecture, 510 the mechanism responsible for the occurrence of the intraplate magmatism of the VVP is still a matter 511 of debate. One of the crucial issues is related to the onset of VVP magmatism. According to the $512{ }^{40} \mathrm{Ar} /{ }^{39} \mathrm{Ar}$ geochronological dating of this study the oldest magmatic activity occurred in the Eocene 513 ( $45 \mathrm{Ma}$ ) rather than in Paleocene, as it was hypothesized in previous studies. Therefore, the onset of 514 VVP magmatism coincided with the Europe-Adria continental collision, which triggered the Alpine 
orogenesis and the orogenic magmatism along the Periadriatic lineament, in particular close to the

516 Giudicarie Fault, where the Adamello intrusive complex emplaced. Considering this, a new 517 geodynamic model is proposed: the Giudicarie Fault is the superficial expression of a vertical 518 lithospheric discontinuity activated in the middle Eocene. This slab tear was responsible for the 519 uprising of an asthenospheric poloidal mantle flow, which migrated toward East at velocities between $520 \quad 0.5$ and $1 \mathrm{~cm} \mathrm{y}^{-1}$, following the general flow of the Earth's mantle. Then the poloidal flow triggered 521 the decompressional melting of the mantle source beneath the VVP region inducing first the main 522 magmatic pulse in the Lessini Mts. district at $45 \mathrm{Ma}$, and other pulses also in Val d'Adige and Berici 523 Hills during middle Eocene, whereas minor pulses in the Euganean and Marostica Hills occurred only 524 during Oligocene and Miocene.

\section{Acknowledgements}

We thank Renzo Tassinari (University of Ferrara) and Maurizio Mazzucchelli (University of Modena and Reggio Emilia) for geochemical analyses, Marcello Serracino (CNR-IGAG, Rome) for EMPA analyses, and Mahdi Ghobadi (Actlabs) for K/Ar analyses. We also thank the two reviewers, Dr. Matt Brueseke and Dr. Iain Neill, for their constructive criticism which improved the earlier version of the manuscript, as well as Dr. Greg Shellnutt for the thoughtful editorial handling.

\section{Funding}

535 Funding for this research was provided by University of Ferrara (FAR fund of Gianluca Bianchini).

References

538 Albarede, F., 1992. How deep do common basaltic magmas form and differentiate?. Journal of 539 Geophysical Research 97, 10997-11009. 
541 Avanzinelli, R., Boari, E., Conticelli, S., Francalanci, L., Guarnieri, L., Perini, G., Petrone, C.M., 542 Tommasini, S., Ulivi, M., 2005. High precision $\mathrm{Sr}, \mathrm{Nd}$, and $\mathrm{Pb}$ isotopic analyses using new 543 generation Thermal Ionisation Mass Spectrometer: aims and perspective for Isotope Geology 544 Applications. Periodico di Mineralogia 74, 147-166.

546 Barberi, F., Santacroce, R., Varet, J., 1982. Chemical aspects of rift magmatism, in: Palmason, G. 547 (Ed.), Continental and Oceanic Rifts. American Geophysical Union, Washington, DC, pp. 223$548 \quad 258$.

Barbieri, G., 1972. Sul significato geologico della faglia di Castelvero (Lessini veronesi). Atti e Memorie Accademiche Patavina SS.LL.AA. 84, 297-302.

Barreca, G., Branca, S., Corsaro, R.A., Scarfì, L., Cannavò, F., Aloisi, M., Monaco, C., Faccenna, C., 2020. Slab detachment, mantle flow, and crustal collision in eastern Sicily (southern Italy):

Bassi, D., Bianchini, G., Mietto, P., Nebelsick, J.H., 2008. Southern Alps: Venetian Pre-Alps, in: McCann, T. (Ed.), The Geology of Central Europe, 2. The Geological Society London, pp. 1087-

Beccaluva, L., Bianchini, G., Bonadiman, C., Coltorti, M., Milani, L., Salvini, L., Siena, F., Tassinari, 1092. R., 2007. Intraplate lithospheric and sublithospheric components in the Adriatic domain: nephelinite to tholeiite magma generation in the Paleogene Veneto Volcanic Province, Southern Alps. Special Paper of Geological Society of America 418, 131-152. 
566 Beccaluva, L., Bianchini, G., Natali, C., Siena, F., 2011. Geodynamic control on orogenic and 567 anorogenic magmatic phases in Sardinia and Southern Spain: Inferences for the Cenozoic 568 evolution of the western Mediterranean. Lithos 123, 218-224.

570 Beccaluva, L., Bonadiman, C., Coltorti, M., Salvini, L., Siena, F., 2001. Depletion events, nature of 571 metasomatizing agent and timing of enrichment processes in lithospheric mantle xenoliths from the VVP. Journal of Petrology 42, 173-187.

Bellieni, G., Fioretti, A.M., Marzoli, A., Visonà, D., 2010. Permo-Paleogene magmtism inthe eastern Alps. Rendiconti Lincei, Scienze Fisiche e Naturali 21, 51-71.

Bergomi, M.A., Zanchetta, S., Tunesi, A., 2015. The Tertiary dike magmaism in the Southern Alps: geochronological data and geodynamic significance. International Journal of Earth Sciences 104, $449-473$.

Bianchini, G., Bell, K., Vaccaro, C., 1999. Mantle sources of the Cenozoic Iblean volcanism (SE Sicily, Italy): Sr-Nd-Pb isotopic constraints. Mineralogy and Petrology 67, 213-221.

Bianchini, G., Beccaluva, L., Siena, F., 2008. Post collisional and intraplate Cenozoic volcanism in

Bianchini, G., Bryce, J.G., Blichert-Toft, J., Beccaluva, L., Natali, C., 2014. Mantle dynamics and secular variations beneath the East African Rift: Insights from peridotite xenoliths (Mega, Ethiopia). Chemical Geology 386, 49-58. 
Bracco Gartner, A.J.J., Seghedi, I., Nikogosian, I.K., Mason, P.R.D., 2020. Asthenosphere-induced melting of diverse source regions for East Carpathian post-collisional volcanism. Contributions to Mineralogy and Petrology 175, 54.

Brack, P., 1984. Geologie der Intrusiva und Nebengesteine des Südwest-Adamello (Nord-Italien). Ph.D. thesis, Dissertation ETH. Nr. 7612.

Brombin, V., Bonadiman, C., Coltorti, M., Fahnestock, M.F., Bryce, J.G., Marzoli, A., 2018. Refertilized mantle keel below the Southern Alps domain (North-East Italy): evidence from Marosticano refractory mantle peridotites. Lithos 300-301, 72-85.

601

Brombin, V., Bonadiman, C., Jourdan, F., Roghi, G., Coltorti, M., Webb, L.E., Callegaro, S., Bellieni,

Bryce, J.G., DePaolo, D.J., 2004. Pb isotopic heterogeneity in basaltic phenocrysts. Geochimica et Cosmochimica Acta 68, 4453-4468.

Callegari, E., Brack, P., 2002. Geological map of the Tertiary Adamello batholith (Northern Italy). Explanatory notes and legend. Memorie di Scienze Geologiche 54, 19-49.

613 Castellarin, A., Vai, G.B., Cantelli, L., 2006. The Alpine evolution of the Southern Alps around the 614 Giudicarie faults: A Late Cretaceous to Early Eocene transfer zone. Tectonophysics 414, $203-223$. 
616 Cebriá, J.M., and Wilson, M., 1995. Cenozoic mafic magmatism in Western/Central Europe: A 617 common European asthenospheric reservoir?: Terra Nova Abstracts 7, 162.

619 Conticelli, S., Guarnieri, L., Farinelli, A., Mattei, M., Avanzinelli, R., Bianchini, G., Boari, E., 620 Tommasini, S., Tiepolo, M., Prelevic, D., Venturelli, G., 2009. Trace-elements and Sr-Nd-Pb 621 isotopes of K-rich, shoshonitic, and calc-alkaline magmatism of the Western Mediterranean 622 region: genesis of ultrapotassic to calcalkaline magmatic association in a post-collisional geodynamic setting. Lithos 107, 69-92.

Davies, J.H., von Blanckenburg, F., 1995. Slab breakoff: a model of lithosphere detachment and its test in the magmatism and deformation of collisional orogens. Earth and Planetary Science Letters 129, 85-102.

De Ritis, R., Pepe, F., Orecchio, B., Casalbore, D., Bosman, A., Chiappini, M., Chiocci, F., Corradino, M., Nicolich, R., Martorelli, E., Monaco, C., Presti, D., Totaro, C., 2019. Magmatism along lateral slab edges: insights from the Diamante-Enotrio-Ovidio volcanic-intrusive complex (Southern

De Vecchi, G., Sedea, R., 1995. The Paleogene basalts of the Veneto region (NE Italy). Memorie di Scienze Geologiche 47, 253-374.

Dézes, P., Schmid, S.M., Ziegler, P.A., 2004. Evolution of the European Cenozoic Rift System: interaction of the Alpine and Pyrenean orogenes with their foreland lithosphere. Tectonophysics 389, 1-33.

Dilek, Y., Altunkaynak, S., 2009. Geochemical and temporal evolution of Cenozoic magmatism in 
Western Turkey: Mantle response to collision, slab break-off, and lithospheric tearing in an orogenic belt. Geological Society London Special Publications 311, 213-233.

Eisele, J., Abouchami, W., Galer, S.J.G, Hofmann, A.W., 2003. The 320 kyr Pb isotope evolution of Mauna Kea lavas recorded in the HSDP-2 drill core. Geochemistry, Geophysics, Geosystems 4,

Faccenna, C., Funiciello, F., Civetta, L., D’Antonio, M., Moroni, M., Piromallo, C., 2007. Slab disruption, mantle circulation, and the opening of the Tyrrhenian basins. Geological Society of America Special Paper 418, 153-169.

Ficini, E., Dal Zilio, L., Doglioni, C., Gerya, T.V., 2017. Horizontal mantle flow controls subduction dynamics. Scientific Reports 7, 7550.

Funiciello, F., Faccenna, C., Giardini, D., 2004. Role of lateral mantle flow in the evolution of subduction systems: insights from laboratory experiments. Geophysical Journal International 157, $1393-1406$.

Handy, M.R., Schmid, S.M., Bousquet, R., Kissling, E., Bernoulli., D., 2010. Reconciling platetectonic reconstructions of Alpine Tethys with the geological-geophysical record of spreading and subduction in the Alps. Earth-Science Reviews 102, 121-158. 
668 Handy, M.R., Ustaszewki, K., Kissling, E., 2015. Reconstructing the Alps-Carpathians-Dinarides as 669 a key to understanding switches in subduction polarity, slab gaps and surface motion. International 670 Journal of Earth Sciences 104, 1-26.

672 Hart, S.R., 1984. A large-scale isotope anomaly in the Southern Hemisphere mantle. Nature 309, $673 \quad 753-757$.

Hoernle, K., Zhang, Y.S., Graham, D., 1995. Seismic and geochemical evidence for largescale mantle upwelling beneath the eastern Atlantic and western and Central Europe. Nature 374, 34-39.

Hua, Y., Zhao, D., Xu, Y., 2017. P wave anisotropic tomography of the Alps. Journal of Geophysical Research Solid Earth 122, 4509-4528.

Hürlimann, N., Müntener, O., Ulmer, P., Nandedkar, R., Chiaradia, M., Ovtcharova, M., 2016. Primary magmas in continental arcs and their differentiated products: petrology of a post-plutonic dyke suite in the Tertiary Adamello batholith (Alps). Journal of Petrology 57, 495-534.

Irvine, T.N., Baragar, W.R.A., 1971. A guide to the chemical classification of the common volcanic rocks. Canadian Journal of Earth Sciences 8, 523-548.

Ji, W.Q, Malusà, M.G., Tiepolo, M., Langone, A., Zhao, L., Wu, F.-Y., 2019. Synchronous 689 Periadriatic magmatism in the Western and Central Alps in the absence of slab breakoff. Terra $690 \quad$ Nova $31,120-128$. 
Kagami, H., Ulmer, P., Hansmann, W., Dietrich, V., Steiger, R.H., 1991. Nd-Sr isotopic and geochemical characteristics of the southern Adamello (Northern Italy) intrusives: implications for crustal versus mantle origin. ournal of Geophysical Research Solid Earth 96, 14331-14346.

Kästle, E.D., Rosenberg, C., Boschi, L., Bellahsen, N., Meier, T., El-Sharkawy, A., 2020. Slab breakoffs in the Alpine Subduction Zone. International Journal of Earth Sciences 109, 587-603.

Lapen, T.J., Johnson, C.M., Baumgartner, L.P., Dal Piaz, V., Skora, S., Beard, B.L., 2007. Coupling of oceanic and continental crust during Eocene eclogite-facies metamorphism: evidence from the Monte Rosa nappe, western Alps. Contributions to Mineralogy and Petrology 153, 139-157.

LaTourette, T., Hervig, R.L., Holloway, J.R., 1995. Trace element partitioning between amphibole, phlogopite, and basanite melt. Earth and Planetary Science Letters 135, 13-30.

Le Maitre, R.W., Streckeisen, A., Zanettin, B., Le Bas, M.J., Bonin, B., Bateman, P., Bellieni, G., Dudek, A., Efremova, S., Keller, J., Lamere, J., Sabine, P.A., Schmid, R., Sorensen, H., Woolley, A.R., 2002. Igneous Rocks: A Classification and Glossary of Terms, Recommendations of the International Union of Geological Sciences Subcommission of the Systematics of Igneous Rocks. Cambridge University Press, UK.

Lee, J.Y., Marti, K., Severinghaus, J.P., Kawamura, K., Yoo, H.-S., Lee, J.B., Kim, J.S., 2006. A redetermination of the isotopic abundance of atmospheric Ar. Geochimica et Cosmochimica Acta $70,4507-4512$.

Lustrino, M., Wilson, M., 2007. The circum-Mediterranean anorogenic Cenozoic igneous province. Earth-Science Reviews 81, 1-65. 
719 Macera, P., Gasperini, D., Piromallo, C., Blichert-Toft, J., Bosch, D., Del Moro, A., Martin, S., 2003. 720 Geodynamic implications of deep mantle upwelling in the source of Tertiary volcanics from the 721 Veneto region (Southern-Eastern Alps). Journal of Geodynamics 36, 563-590.

Macera, P., Gasperini, D., Ranalli, G., Mahatsente, R., 2008. Slab detachment and mantle plume upwelling in subduction zones: an example from the Italian South-Eastern Alps. Journal of Geodynamics 45, 32-48.

Malusà, M.G., Faccenna, C., Garzanti, E., Polino, R., 2011. Divergence in subduction zones and exhumation of high pressure rocks (Eocene Western Alps). Earth and Planetary Science Letters $310,21-32$.

Mats, V.D., Perepelova, T.I., 2011. A new perspective on evolution of the Baikal Rift. Geoscience Frontiers 2, 349-365.

McDonough, W.F., Sun, S.S., 1995. The composition of the Earth. Chemical Geology 120, 223-253.

Medizza, F., 1965. Ricerche micropaleontologico-stratigrafiche sulle formazioni al limite tra Cretaceo e Terziario nell'alta Valle del Chiampo (Lessini Orientali). Memorie dell'Istituto Geologico Mineralogico dell' Università di Padova 25, 1-41.

Merle, R., Marzoli, A., Aka, F.T., Chiaradia, J.M., Reisberg, L., Castorina, F., Jourdan, F., Renne, P.R., N'ni, J., Nyobe, J.B., 2017. Mt. Bambouto Volcano, Cameroon Line: mantle source and differentiation of within-plate alkaline rocks. Journal of Petrology 58, 933-962. 
Milani, L., Beccaluva, L., Coltorti, M., 1999. Petrogenesis and evolution of the Euganean magmatic complex, north eastern Italy. European Journal of Mineralogy 11, 379-399.

Moine, B.N., Grégoire, M., O'Reilly, S.Y., Sheppard, S.M.F., Cottin, J.Y., 2001. High field strenght elemental fractionation in the Upper Mantle: evidence from amphibole-rich composite mantle xenoliths from the Kerguelen Islands (Indian Ocean). Journal of Petrology 11, 2145-2167.

Morten, L., Taylor, L.A., Durazzo, A., 1989. Spinel in harzburgite and lherzolite inclusions from the San Giovanni Ilarione Quarry, Lessini Mountains, Veneto Region, Italy. Mineralogy and Petrology 40, 73-89.

Papazzoni, C.A., Giusberti, L., Carnevale, G., Roghi, G., Bassi, D., Zorzin, R., 2014. The Bolca Fossil-Lagerstätten: a window into the Eocene World. Rendiconti della Società Paleontologica Italiana 4.

Petrescu, L., Pondrelli, S., Salimbeni, S., Faccenda, M., AlpArray Working Group, 2020. Mantle flow below the central and greater Alpine region: insights from SKS anisotropy analysis at AlpArray and permanent stations. Solid Earth 11, 1275-1290.

Prelević, D., Akal, C., Romer, R.L., Mertz-Kraus, R., Helvaci, C. Magamtic response to slab tearing: constraints from the Afyon alkaline volcanic complex, Western Turkey. Journal of Petrology 56, $527-562$.

Roeder, P.L., Emslie R.F., 1970. Olivine-liquid equilibrium. Contributions to Mineralogy and Petrology 29, 275-289. 
Rosenbaum, G., Lister, G.S., 2005. The Western Alps from the Jurassic to Oligocene: spatio-temporal constraints and evolutionary reconstructions. Earth-Science Reviews 69, 281-306.

Rubatto, D., Hermann, J., 2001. Exhumation as fast as subduction? Geology 29, 3-6.

Rubatto, D., Gebauer, D., Fanning, M., 1998. Jurassic formation and Eocene subduction of the Zermatt-Saas-fee ophiolites: implications for the geodynamic evolution of the Central and Western Alps. Contributions to Mineralogy and Petrology 132, 269-287.

Salimbeni, S., Malusà, M. G., Zhao, L., Guillot, S., Pondrelli, S., Margheriti, L., et al. 2018. Active and fossil mantle flows in the western Alpine region unravelled by seismic anisotropy analysis and high-resolution $\mathrm{P}$ wave tomography. Tectonophysics 731-732, 35-47.

Schaltegger, U., Nowak, A., Ulianov, A., Fiscer, C.M., Gerdes, A., Spikings, R., Whitehouse, M.J., Bindeman, I., Hanchar, J.M., Duff, J., Vervoort, J.D., Sheldrake T., Caricchi, L., Brack, P., Müntener, O., 2019. Zircon Petrochronology and ${ }^{40} \mathrm{Ar} /{ }^{39} \mathrm{Ar}$ Thermochronology of the Adamello Intrusive Suite, N. Italy: Monitoring the Growth and Decay of an Incrementally Assembled Magmatic System. Journal of Petrology 60, 701-722.

Siena, F., Coltorti, M., 1989. Lithospheric mantle evolution: evidences from ultramafic xenoliths in the Lessinean volcanics (Northern Itlay). Chemical Geology 77, 347-364.

Siena, F., Coltorti, M., 1993. Thermobarometric evolution and metasomatic processes of upper mantle in different tectonic settings: evidence from spinel peridotite xenoliths. European Journal of Mineralogy 5, 1073-1090. 
796 Stampfli, G.M., Borel, G.D., Marchant, R., Mosar, J., 2002. Western Alps geological constraints on 797 western Tethyan reconstruction, in: Rosenbaum, G., Lister, G.S. (Eds.), Reconstruction of the 798 evolution of the Alpine-Himalayan Orogen. Journal of the Virtual Explorer 7, pp. 75-104.

800 Stampfli, G.M., Mosar, J., Marquer, D., Marchant, R., Baudin, T., Borel, G., 1998. Subduction and 801 obduction processes in the Swiss Alps. Tectonophysics 296, 159-204.

802

Sun, S.S., McDonough, W.F., 1989. Chemical and isotopic systematics of oceanic basalts: 804 Implications for mantle composition and processes, in: Saunders, A.D., Norry, M.J. (Eds.), 805 Magmatism in the Oceanic Basins. Geological Society, London, Special Publications 42, pp. 313 $806 \quad 346$

Svensen, H.H., Torsvik, T.H., Callegaro, S., Augland, L., Heimdal, T.H., Jerram, D.A., Planke, S., 809 Pereira, E. 2018. Gondwana Large Igneous Provinces: plate reconstructions,volcanic basins and sill volumes. Geological Society, London, Special Publications 463, 17-40.

Visonà, D., Caironi, V., Carraro, A., Dallai, L., Fioretti, A.M., Fanning, M., 2007. Zircon megacrysts 813 from basalts of the venetian Volcanic Province (NE Italy): U-Pb, oxygen isotopes and REE data. $814 \quad$ Lithos 94, 168-180.

816 Wiederkehr, M., Sudo, M., Bousquet, R., Berger, A., Schmid, S.M., 2009. Alpine orogenic evolution 817 from subduction to collisional thermal overprint: The ${ }^{40} \mathrm{Ar} /{ }^{39} \mathrm{Ar}$ age constraints from the Valaisan 818 Ocean, central Alps. Tectonics 48, TC6009. 
Wilson, M., Bianchini, G., 1999. Tertiary-Quaternary magmatism within the Mediterranean and surrounding regions. Geological Society, London, Special Publications 156, 141-168.

Wilson, M., Downes, H., 2006. Tertiary-Quaternary intra-plate magmatism in Europe and its relationship to mantle dynamics, in: Gee, D., Stephenson, R. (Eds.), European Lithosphere Dynamics. Geological Society, London, Memoirs 32, pp. 147-166.

Zhao L., Paul A., Malusà M.G., Xu X., Zheng T., Solarino S., Guillot S., Schwartz S., Dumont T., Salimbeni S., Aubert C., Pondrelli S., Wang Q., Zhu R., 2016. Continuity of the Alpine slab unraveled by high-resolution P wave tomography. Journal of Geophysical Research Solid Earth $121,8720-8737$.

Zindler, A., Hart, S., 1986. Chemical geodynamics. Annual Review of Earth and Planetary Sciences $14,493-571$.

\section{Figure captions}

No color should be used for any figures in print.

Fig. 1. Simplified geological map of the Veneto Volcanic Province (VVP), showing the locations of the samples collected for this work and the obtained ages (see section 4.3). The new ages are framed with black lines, whereas literature ages are framed with red lines (from Brombin et al., 2019 and references therein). Inset (a) location of the VVP in the Italian peninsula, general view of the major lithospheric plates involved in the area, and distribution of other Cenozoic volcanic occurrences in the Adria microplate having intraplate c affinity. Abbreviations: QU: Mount Queglia; PN: Pietre Nere. Inset (b) VVP spatial distribution in relation to the surrounding orogenic belts with locations of Periadriatic intrusive bodies along the Periadriatic line and the relative intrusive rock ages (from 
845 Kästle et al., 2020 and reference therein). Abbreviations: Tr: Traversella; Bi: Biella; Br: Bregaglia; 846 Ad: Adamello; R=Rensen.

848 Fig. 2. a) Total Alkali vs. Silica (TAS) classification diagram (Le Maitre et al., 2002), reporting the 849 composition of VVP samples studied in this work (large symbols) and that reported in the literature 850 (small symbols; Beccaluva et al., 2007; Brombin et al., 2019; Macera et al., 2003; Milani et al., 1999). 851 The alkaline-tholeiitic discrimination line is from Irvine and Bargar (1971). b) Primordial mantle852 normalized (McDonough and Sun; 1995) incompatible trace element patterns of VVP samples 853 studied in this paper, compared with those of other VVP products (shaded area) retrieved from the 854 literature (Beccaluva et al., 2007; Brombin et al., 2019; Macera et al., 2003). The black dashed line 855 is for Ocean Island Basalt composition (OIB; Sun and McDonough, 1989). The (average) trace 856 element pattern of basic dykes from the Adamello plutonic complex (Hürlimann et al., 2016) is also reported for comparison.

Fig. 3. Crossed-polarizers representative photomicrographs of the investigated VVP samples. Abbreviation: $\mathrm{Ol}=$ olivine, $\mathrm{Cpx}=$ clinopyroxene, $\mathrm{Pl}=$ plagioclase.

Fig. 4. Sr-Nd-Pb isotopic composition of VVP samples studied in this work (large symbols) compared with those of VVP products retrieved from the literature (Beccaluva et al., 2007; Macera et al., 2003; Milani et al., 1999), those of other Cenozoic volcanic occurrences (Mount Queglia, Pietre Nere) of the Adria microplate (Bianchini et al., 2008), and those of basic dykes from the Adamello plutonic complex (Hürlimann et al., 2016). Fig. b, d, and f are zoom portions of a, c, and e, respectively. Geochemical components depleted mantle $(\mathrm{DMM})$, HIMU (high $\mathrm{U} / \mathrm{Pb}=$ high $\mu$ ), EMI and EMII (enriched mantle) are after Zindler and Hart (1986); European Asthenospheric Reservoir (EAR) is after Cebriá and Wilson (1995). The Northern Hemisphere Reference Line is from Hart (1984). 
871 Fig. 5. ${ }^{39} \mathrm{Ar} /{ }^{40} \mathrm{Ar} v{ }^{36} \mathrm{Ar} /{ }^{40} \mathrm{Ar}$ inverse isochrons and ${ }^{40} \mathrm{Ar} /{ }^{39} \mathrm{Ar}$ apparent age spectra plotted against the 872 cumulative percentage of ${ }^{39} \mathrm{Ar}$ released for VVP samples.

873

874 Fig. 6. a) Average volumes of magmatic products occurred in Lessini Mts., Euganean Hills, and 875 Marostica Hills districts from Eocene to Miocene (this work) and average volume of magmatic 876 products occurred in the Adamello complex from Eocene to Oligocene (Schaltegger et al., 2009). The 877 dotted lines indicate the ages of magmatic activities, that should be considered questionable, as 878 derived from old K-Ar or Rb-Sr dating techniques, which are less reliable than Ar-Ar method (see 879 Brombin et al., 2019 for a review). b) Schematic cartoon (not in scale) for the magmatism of Adamello 880 complex along the Periadriatic Line (Central Alps) and the VVP (Southeastern Alps) during Eocene881 Oligocene. Through the vertical slab tear, located near the Giudicarie fault zone, upwelling mantle 882 with a poloidal flow melted and led to Adamello complex magmatism. Coherently with the general 883 Earth mantle flow, the poloidal flow migrated toward East and also triggered the intraplate 884 magmatism in the VVP. 